\title{
Cumulative changes in water quality caused by six cascading hydroelectric dams on the Jauru River, tributary of the Pantanal floodplain
}

\section{Mudanças cumulativas na qualidade da água causadas por seis hidrelétricas em cascata no Rio Jauru, tributário da planície de inundação do Pantanal}

\author{
Antônio Carlos Coelho da Silva ${ }^{1,2}$, Ibraim Fantin-Cruz ${ }^{2}$, Zoraidy Marques de Lima ${ }^{2}$ \\ and Daniela Maimoni de Figueiredo ${ }^{2}$ (D)
}

${ }^{1}$ Instituto Federal de Educação, Ciência e Tecnologia de Mato Grosso, Cuiabá, MT, Brasil

${ }^{2}$ Universidade Federal de Mato Grosso, Cuiabá, MT, Brasil

E-mails: engenheiroantoniocarlos@hotmail.com (ACCS),ibraimfantin@gmail.com (IFC), zoraidy@terra.com.br (ZML), dani_figueiredo@uol.com.br(DMF)

\begin{abstract}
The present study examines the individual and cumulative environmental effects of the six cascading hydroelectric dams currently in operation on in the Jauru River, a direct tributary of the Paraguay River, the main river in the Pantanal, as well as presenting a general characterization of water quality in the Jauru River. Water quality was evaluated at eight sites along the longitudinal gradient of the Jauru River. A total of 339 water quality samples from between 1990 and 2013 were considered, including 72 samples collected prior to the installation of Hydropower plants, treated as natural, and 267 samples, treated as altered. Statistica 7 software was used for statistical treatment and for the Kruskal-Wallis nonparametric test; squared Pearson correlation (coefficient of determination, $\mathrm{R}^{2}$ ) was also applied to evaluated the relationship between the morphological and hydraulic parameters of each reservoir and cumulatively, with the rate of change of water quality parameters in three stretches of the Jauru River. The water quality of the Jauru River in general was characterized by low concentrations of electrolytes and slightly acidic $\mathrm{pH}$, oligotrophy, reduced values of color, turbidity and solids and good oxygenation. While these general conditions were maintained over the two phases studied, we verified the occurrence of change in the pattern of variation of the physical and chemical conditions evaluated, mainly between the second and the fifth hydroelectric reservoir. This change, which implies discontinuity in the longitudinal gradient, was indicated by nine out of the twelve parameters measured in this stretch of the Jauru River, downstream of each individual reservoir and/or cumulatively. The constructive characteristics of the hydropower plants, especially water inlet height, water retention time and flooded area, as well as the proximity between two or more impoundments, are factors that influenced the observed changes, which are important aspects in the processes of environmental licensing for these future plants, or even, in some cases, to avoid them from being built at all as planned. This research also indicated the need for studies that consider the basin in an integrated way, and for the collection of more consistent data before these impoundments are implemented.
\end{abstract}

Keywords: Wetland; Ecohydrology; Watershed.

\section{RESUMO}

O presente estudo avalia as alterações na qualidade da água, individuais e cumulativas, de seis hidrelétricas (HPP) em cascata, que estão em operação no Rio Jauru, um afluente direto do rio Paraguai, o principal rio da planície de inundação do Pantanal, além de apresentar uma caracterização geral da qualidade da água do Rio Jauru. A qualidade da água foi avaliada em oito locais ao longo do gradiente longitudinal do rio Jauru. Foram avaliadas um total de 339 amostras de qualidade de água entre 1990 e 2013 , sendo que 72 representam a fase antes da instalação e 267 amostras a fase de após a instalação das HPP. O software Statistica 7 foi utilizado para tratamento estatístico e Kruskal-Wallis para o teste não paramétrico; foi adotado também a Correlação de Pearson ao quadrado (coeficiente de determinação, R2) para avaliar a relação entre os parâmetros morfológicos e hidráulicos de cada reservatório e cumulativamente, com a taxa de variação dos parâmetros de qualidade da água em três trechos do rio Jauru. A qualidade da água do Rio Jauru, em geral, foi caracterizada por 
baixas concentrações de eletrólitos e pH levemente ácido, oligotrofia, redução de cor, turbidez e sólidos e boa oxigenação. Apesar dessas condições gerais terem se mantido nas duas fases estudadas, verificou-se a ocorrência de mudança no padrão de variação das condições físico-químicas avaliadas, principalmente entre o segundo e o quinto reservatório hidrelétrico. Essa mudança, que implica na descontinuidade no gradiente longitudinal, foi indicada por nove dos doze parâmetros medidos nesse trecho do Rio Jauru, a jusante de cada reservatório individual e/ou cumulativamente. As características construtivas das usinas hidrelétricas, especialmente a altura da tomada d'água, o tempo de retenção e a área alagada, bem como a proximidade entre dois ou mais reservatórios, são fatores que influenciaram as mudanças observadas e são aspectos importantes a serem considerados nos processos de licenciamento ambiental de futuras hidrelétricas, ou mesmo, em alguns casos, para evitar que sejam construídas como planejado. Esta pesquisa indicou ainda a necessidade de estudos que considerem a bacia hidrográfica de forma integrada e de efetuar uma coleta de dados mais consistentes antes que esses represamentos sejam implementados.

Palavras-chave: Área úmida; Ecohidrologia; Bacia hidrográfica.

\section{INTRODUCTION}

Hydropower plants are regarded as sources of clean, renewable, low carbon energy and, in the case of Small Hydropower Plants (SHPPs), of low negative environmental impacts. These factors, coupled with government incentives in several countries in recent years, have favored the proliferation of SHPPs in small and medium sized rivers around the world, as shown by Kibler and Tullos (2014) in the database of the Clean Development Mechanism (CDM) defined in the Kyoto Protocol. However, there is some controversy over the significant quantities of methane and carbon dioxide emitted by hydroelectric projects, particularly in tropical regions (FEARNSIDE, 2015).

Individually, SHPPs cause fewer negative environmental impacts than hydropower plants (HPP). However, their cumulative effect, when two or more are constructed in sequence on the same river, can be similar (MALVEIRA; ARAÚJO; GÜNTNER, 2012), and this is often difficult to predict, given the scarcity of information, the complexity of quantifying these effects and the small numbers of studies using systemic approaches that take synergistic effects into account (DEITCH; MERENLENDER; FEIRER, 2013; KUMAR; KATOCH, 2014). Thus, research into cumulative effects in river basins or stretches with several small reservoirs at the planning stage (CARDOSO et al., 2015) or already in operation (CRUZ, 2018; DEITCH; MERENLENDER; FEIRER, 2013) has only recently started to appear in the scientific literature, representing a new approach in environmental studies. This lack of information is also a limiting factor for the implementation of legal and technical mechanisms to support the environmental licensing process of SHPPs, thus also posing a challenge for environmental management. In Brazil, Integrated Environmental Assessments (IEA) are rare, but necessary in basins where numerous hydroelectric plants are planned or in operation; thus far, none have been carried out in Pantanal tributaries.

The magnitude of the alterations that each hydroelectric project (HPP) causes in a river varies according to the plant's constructive characteristics determining flooded area, accumulated volume, hydraulic retention time, flow regulation capacity, position of the water inlet and spillway, and length of the adductor channel and reduced flow section. All of these influence the quality of the water released downstream, as does the hydrological regime (NALIATO; NOGUEIRA; PERBICHE-NEVES, 2009; FANTIN-CRUZ et al., 2015a). These changes are well-known and predictable in medium- and large-scale developments, but there are uncertainties regarding the extent to which they can be generalized to SHPPs whether isolated or in sequence on the same river, either in terms of the direction of change (positive or negative) or in the degree and magnitude of these changes.

This becomes even more relevant when SHPPs are built upstream of floodplains (FANTIN-CRUZ et al., 2015a), as plants may have direct and indirect consequences for the ecological functioning of these important ecosystems. In the case of the Pantanal, the largest continuous floodplain in the world, with recognized environmental significance as a Brazilian National Heritage Site and a UNESCO Natural World Heritage Site and Biosphere Reserve, and with two wetland areas listed on RAMSAR (List of Wetlands of International Importance), changes in the dynamics of aquatic ecosystems can have irreversible consequences (JUNK et al., 2011; CALHEIROS; OLIVEIRA, 2011). In recent years, several surveys have been carried out on Pantanal tributary rivers demonstrating that the changes of anthropogenic origin affecting this plain come mainly from the high and middle reaches of these rivers, on the plateaus and depressions, where human occupation is more dense and diverse than in the plain (JUNK et al., 2011; ZEILHOFER et al., 2016). Some of these changes result from large-scale agro-industry, while others are caused by river damming for electric power generation (FANTIN-CRUZ et al., 2015a; JUNK et al., 2014). 44 hydroelectric power plants are currently operating in the Upper Paraguay Basin (UPB), of which 36 are SHPPs; with an estimated 116 more projects due to be built.

There is, therefore, a pressing need to investigate the cumulative ecohydrological impacts of hydroelectric dams and to find out how these types of dams can be better managed or constructed to reduce their negative effects (FANTIN-CRUZ et al., 2015b), especially when located upstream of floodplains; there has so far been little work with this focus on Pantanal tributaries (FANTIN-CRUZ et al., 2015a,b).

With this in mind, the present study examines the individual and cumulative environmental effects of the six cascading hydroelectric dams currently in operation on in the Jauru River, a direct tributary of the Paraguay River, the main river in the Pantanal, as well as presenting a general characterization of water quality in the Jauru River. This research sought to answer the following questions: do changes occur in water quality downstream of each hydropower plant? What are these changes and how significant are they? Are they cumulative, and do they affect the floodplain? 


\section{Study area}

One of the 12 Brazilian Hydrographic Regions, Paraguay has an area of $362,259 \mathrm{~km}^{2}$ and covers parts of the States of Mato Grosso and Mato Grosso do Sul, as well as parts of Paraguay and Bolivia; the area is denominated regionally as the Upper Paraguay Basin (UPB). Of this total area, 9.21\% belongs to the sub-basin of the Jauru River, a direct tributary of the Paraguay River, which is $412 \mathrm{~km}$ long and has an average flow of $170.7 \mathrm{~m}^{3} \mathrm{~s}^{-1}$. The drainage area, about $15,844 \mathrm{~km}^{2}$, is located at latitudes $14^{\circ} 29^{\prime} \mathrm{S}$ and $16^{\circ} 30^{\circ} \mathrm{S}$ and longitudes $57^{\circ} 45^{\prime} \mathrm{W}$ and $59^{\circ} 15^{\prime} \mathrm{W}$ (SOUZA; SOUSA; SILVA ANDRADE, 2012); $7.45 \%$ of this area is in the Pantanal plain (Figure 1).

The main right bank tributaries of the Jauru River are the Brigadeiro and Aguapeí rivers and the Santíssimo stream, while the main tributaries on the left bank are the Sangue, Água Suja and Pitas streams (SOUZA; SOUSA; SILVA ANDRADE, 2012). These authors describe how the Jauru reaches the floodplain of the Pantanal, forming a kind of fan, and some small water courses drain the areas subject to flooding, either draining into bays and lakes or spreading into the plain. The average annual flow is $59.2 \mathrm{~m}^{3} \cdot \mathrm{s}^{-1}$, in the high reach, $86 \mathrm{~m}^{3} \cdot \mathrm{s}^{-1}$ in the middle course and about $100 \mathrm{~m}^{3} \cdot \mathrm{s}^{-1}$ in the low course.

The main soil classes of the Jauru River Basin are Podzolic, Latosols, Quartz Sand and Plinthosols. For vegetation typology, the main formations are savannahs (wooded savannah-cerrado, forested savannah-cerrado) and contact (seasonal forest/savannah contact) formations and anthropic areas (pasture). In terms of geology, there is the Utiariti formation, the Jauru formation, the Xingu complex and the Pantanal formation (MOURA; CARVALHO; PEREIRA, 2011). As far as land use is concerned, livestock activity predominates (56.8\%), followed by native and remnant vegetation $(32.5 \%)$ and mechanized agriculture $(10.1 \%)$ (ANDRADE et al., 2012).

The climate is Aw, sub-humid tropical, according to the Köppen classification; characterized by two well-defined seasons: a rainy season from October to April and a dry season from May to September, although with variations as to the onset, end and duration of the same. During most of the year, the temperature is high, easily surpassing $35^{\circ} \mathrm{C}$, but on some days of the year the temperature may drop, usually in the months of June and/or July, with temperatures falling to $10^{\circ} \mathrm{C}$ or less (MOURA; CARVALHO; MARTINHAGO, 2009).

\section{Characterization of hydropower plants}

There is currently no international standard definition of SHPP (CRUZ, 2018). Under Brazilian legislation, Small Hydro Power Plants (SHPP) are hydroelectric plants that produce between 3 and $30 \mathrm{MW}$ of power (BRASIL, 2015) and have a reservoir smaller than $13 \mathrm{~km}^{2}$; a plant producing more power or with a larger flooded area is defined as a Hydro Power Plant (HPP) (Table 1). However, in China SHPPs are those producing up $50 \mathrm{MW}$, significantly higher than the levels adopted by Brazil, Europe (10 MW), the United States and India (25 MW) (HENNIG et al., 2013).

The existing operational hydropower plants installed in cascade in the Jauru River are, from upstream to downstream:

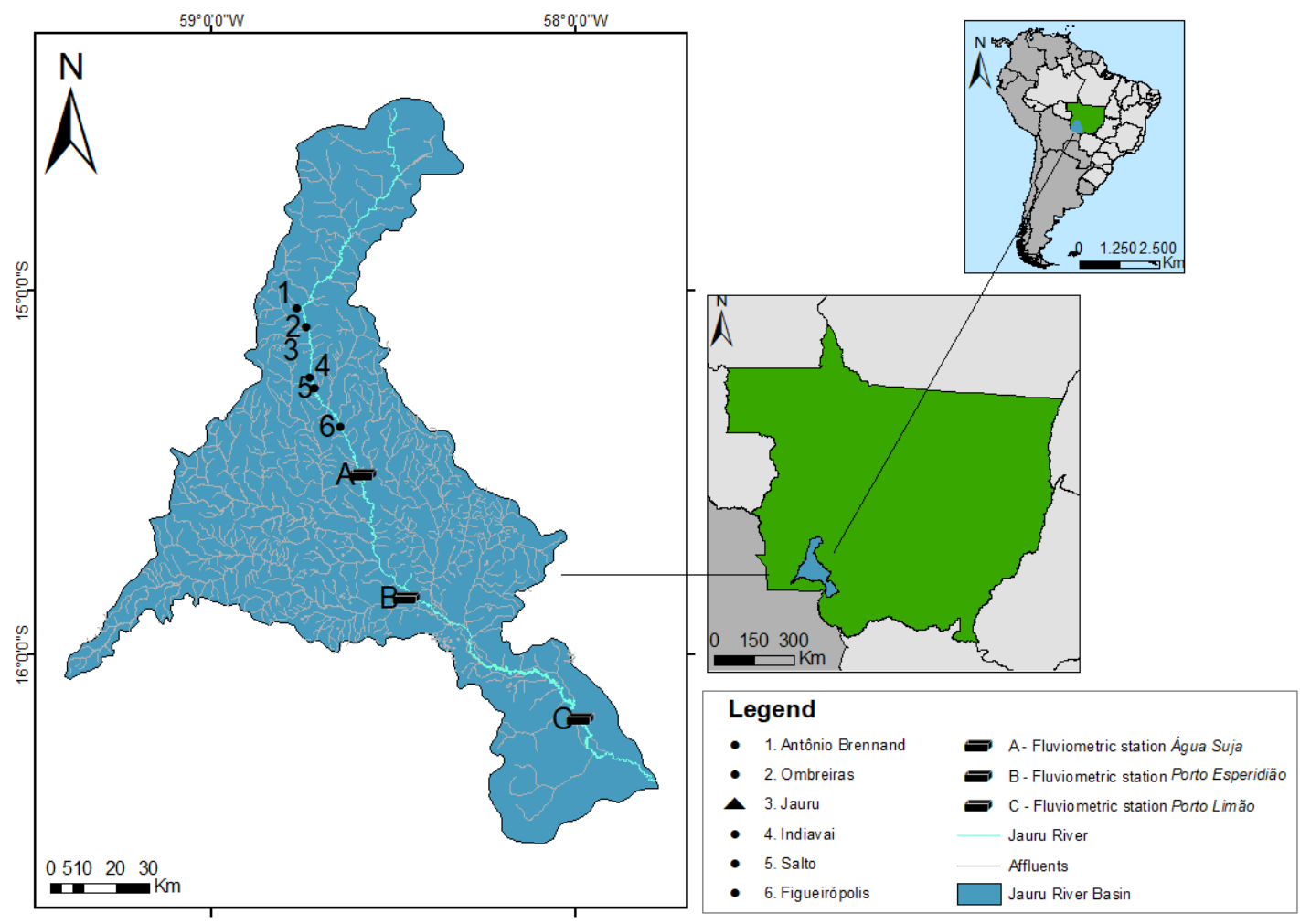

Figure 1. Location of the Jauru River basin, hydroelectrical plants (1-6) and fluviometric stations (A, B and C). 
Table 1. Data and constructive characteristics of the six hydropower plants in operation in the Jauru River, from upstream to downstream.

\begin{tabular}{|c|c|c|c|c|c|c|}
\hline Hidropower Plant & $\begin{array}{c}\text { Antonio } \\
\text { Brennand } \\
\text { SHPP }\end{array}$ & $\begin{array}{c}\text { Ombreiras } \\
\text { SHPP }\end{array}$ & $\begin{array}{l}\text { Jauru } \\
\text { HPP }\end{array}$ & $\begin{array}{l}\text { Indiavaí } \\
\text { SHPP }\end{array}$ & $\begin{array}{l}\text { Salto } \\
\text { SHPP }\end{array}$ & $\begin{array}{c}\text { Figueirópolis } \\
\text { SHPP }\end{array}$ \\
\hline Start date of operation & July-2013 & July-2005 & June-2003 & August-2003 & Februa-2008 & October-2010 \\
\hline Contribution basin $\left(\mathrm{km}^{2}\right)$ & 1590 & 2207 & 2620 & 2320 & 2460 & 2960 \\
\hline Flooded area $\left(\mathrm{km}^{2}\right)$ & 0.03 & 1.21 & 1.93 & 0.27 & 0.79 & 7.26 \\
\hline $\begin{array}{l}\text { Longitudinal lenght of the } \\
\text { reservoir }(\mathrm{km})\end{array}$ & 0.28 & 7.3 & 8.2 & 2.2 & 3.7 & 18 \\
\hline Hydraulic residense time (day) & 0.04 to 0.08 & 4.2 to 6.8 & 3 to 5 & 0.32 to 0.58 & 0.35 to 0.60 & 5.6 to 8.0 \\
\hline Installed power (MW) & 22.0 & 26.0 & 121.5 & 28.0 & 19.0 & 19.4 \\
\hline
\end{tabular}

Antônio Brennand SHPP, Ombreiras SHPP, Jauru HPP, Salto SHPP, Indiavaí SHPP and Figueirópolis SHPP (Figure 1 and Table 1).

Regarding water retention time (WRT), according to Conama Resolution (National Council for the Environment) no 357/2005 (BRASIL, 2005), only the Ombreira and Figueirópolis SHPPs and the Jauru HPP have reservoirs classified as intermediate environments ( 2 days $<$ WRT $<40$ days). The others are considered under this legislation as lotic environments, with WRT $<2$ days, and none of the reservoirs are typically lentic environments (WRT $>40$ days). The sequence of hydroelectric plants in the Jauru River forms a discontinuous stretch of more than $32 \mathrm{~km}$, located in a continuous stretch of $54 \mathrm{~km}$ between the first and last hydropower plant.

\section{MATERIAL AND METHODS}

Water quality was evaluated at eight sites along the longitudinal gradient of the Jauru River, namely: BRE upstream of the Antônio Brennand SHPP and all the HPPs (Hydro Power Plants); OMB between SHPPs Antônio Brennand and Ombreiras; JAU between Ombreiras SHPP and Jauru HPP; IND between Jauru HPP and Indiavaí SHPP; SAL between SHPPs Indiavaí and Salto SHPPs; UP_FIG between PCHs Salto and Figueirópolis; DOW_FIG downstream of Figueirópolis SHPP and F_PLAIN at the fluviometric station ANA 66077100 (Porto Limão), in the floodplain (Figure 1 and Table 1).

The following physical and chemical parameters were evaluated: water temperature, $\mathrm{pH}$, color, turbidity, electrical conductivity, chemical oxygen demand (COD), biochemical oxygen demand (BOD), dissolved oxygen (DO), total phosphorus, total nitrogen, suspended solids and total solids. Methods used for field measurements, collection, preservation and laboratory analyses are described in AWWA/APHA (previous editions, 2005 and 2012) (APHA, 2005, 2012). For parameters that presented values below or above the limit of detection of the method, limit values were adopted as representative.

A total of 339 water quality samples from between 1990 and 2013 were considered, including 72 samples collected prior to the installation of HPPs (Hydro Power Plants), treated as natural, and 267 samples, treated as altered, collected after Antônio Brennand SHPP, Jauru HPP and Indiavaí SHPP became operational in 2003. That is, from the time these plants became operational, it was considered that the whole of the downstream stretch went from the natural phase to the altered phase. Data on water quality were obtained from the National Water Agency (ANA), the Environment Department of the State of Mato Grosso (SEMA-MT) and environmental impact and monitoring studies (operational phase) carried out by the hydroelectric plants. The sections of the river where there were fewer than four samplings during the natural phase, were ignored, as this was considered to be insufficient data, but are included in the graphs and tables.

Fluviometric stations with available quantitative data are located at only three points along the Jauru River (Figure 1), all downstream of the six hydroelectric dams. This did not allow for an adequate comparison between these data and the water quality measurements in the present study.

The medians of the water quality parameters at the sites BRE to DOW_FIG were adopted to characterize the changes in the plateau area comprising the hydropower dams, and the median at F_PLAIN for changes in the floodplain.

Statistica 7 software was used for statistical treatment and for the Kruskal-Wallis nonparametric test, which was applied to test whether the sets of samples before and after the installation of the HPP were significantly different ( $\mathrm{p} \leq 0.05)$.

The rate of change in water quality before and after the installation of the hydropower plants (natural and altered) in the various sites was determined from the ratio of the medians of these values (Equation 1), from each site studied, where a positive value indicated an increase and a negative value a decrease in the median values after the installation of the hydropower plants.

Rate of change $=\frac{\text { Altered }- \text { Natural }}{\text { Natural }}$

Using the squared Pearson correlation (coefficient of determination, $\mathrm{R}^{2}$ ), we evaluated the relationship between the morphological and hydraulic parameters of each reservoir (flooded area, reservoir length and WRT, Table 1) and cumulatively, with the rate of change of water quality parameters in three stretches of the Jauru River. In this context, site BRE was not considered, because it is upstream of the first hydropower plant, and nor was F_PLAIN, which is in the floodplain region. For this test, between $\mathrm{OMB}$ and SAL, data were considered from Antônio Brennand SHPP, Ombreiras SHPP, Jauru HPP and Indiavaí SGP; from OMB to UP_FIG, in addition to those cited, Salto SHPP; and from OMB to DOW_FIG, all the hydroelectric plants. 


\section{RESULTS}

In terms of the variation in water quality in the longitudinal gradient of the Jauru River in the natural and altered phases, water temperature was slightly higher between the downstream of the first and the last hydropower plant (JAU-DOW-FIG) in the altered phase (Figure 2), although the difference was not significant between these phases for the entire data set available (Table 2).
As for $\mathrm{pH}$, the majority of the results were below neutral, especially in the upper and middle sections of the river, with a slight tendency of reduction in the altered phase, significant only in IND. In the lower part of the Jauru River, the $\mathrm{pH}$ was higher and slightly above neutral (Figure 2).

The color values found in BRE, OMB, IND and SAL were the same in both phases considered (2.4 units). After the a)

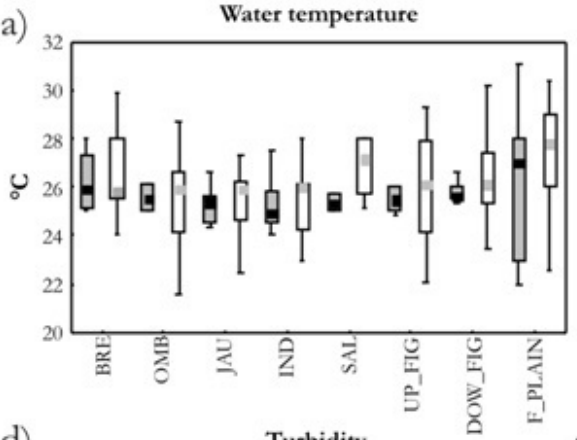

d)
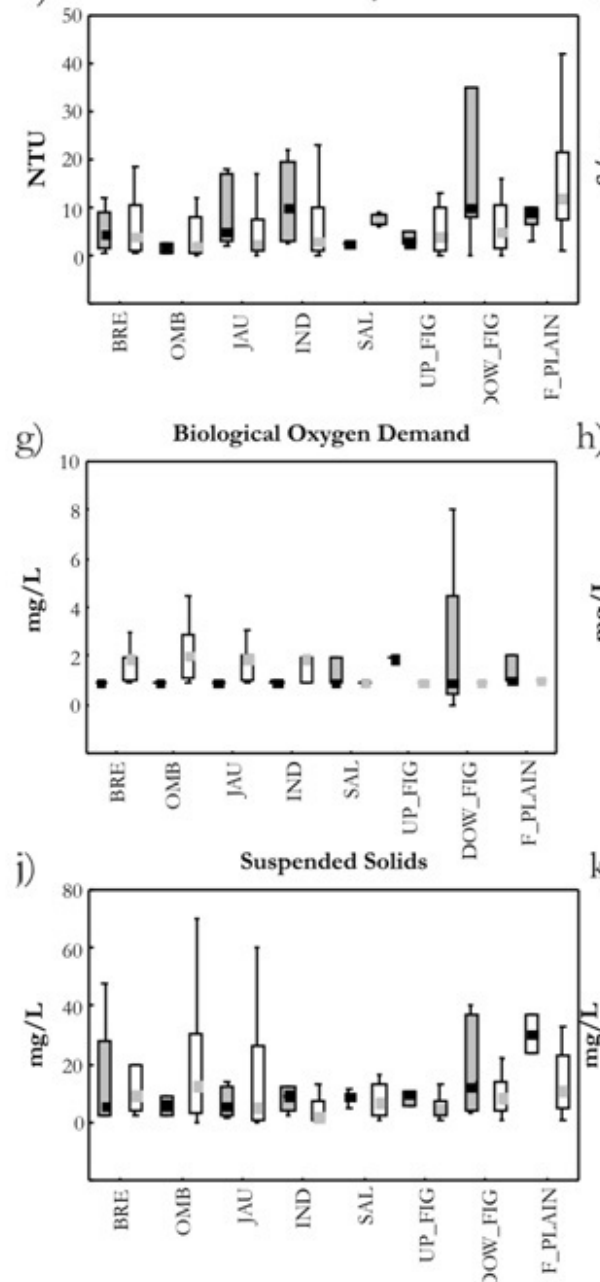

b)

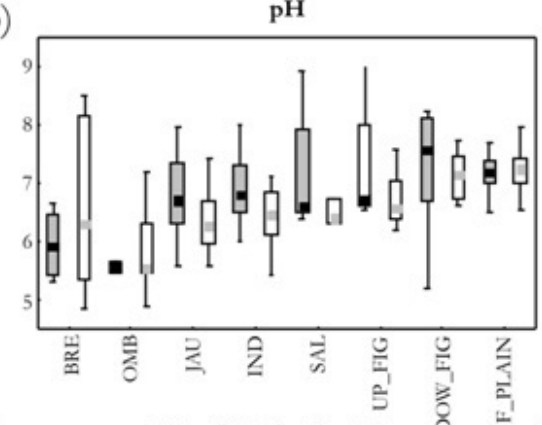

e)

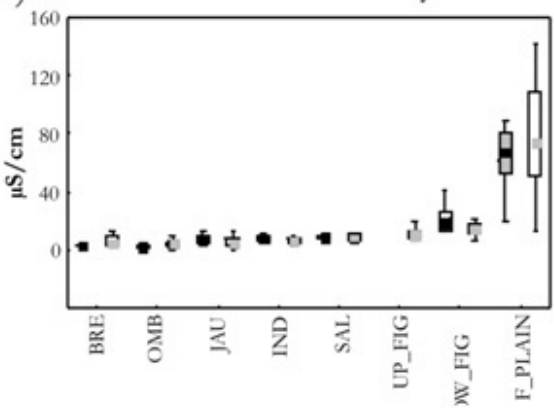

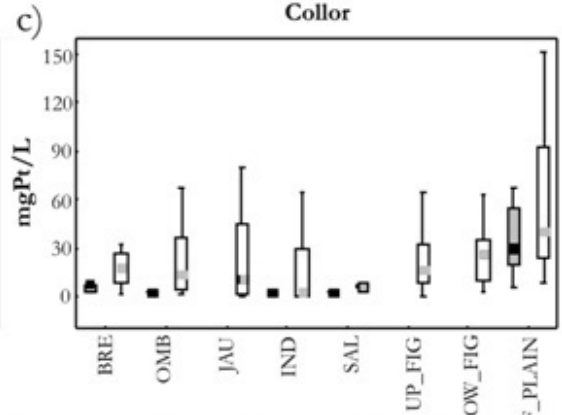

f)

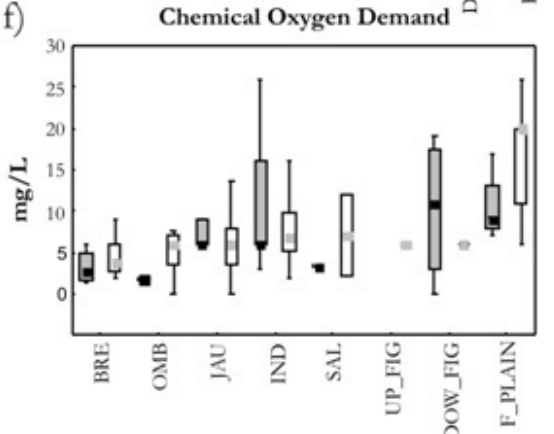

h)
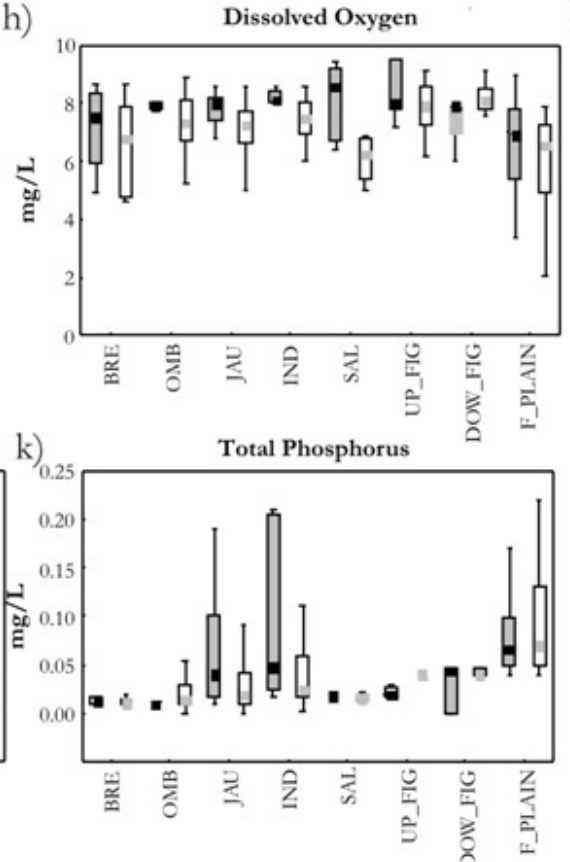

i)

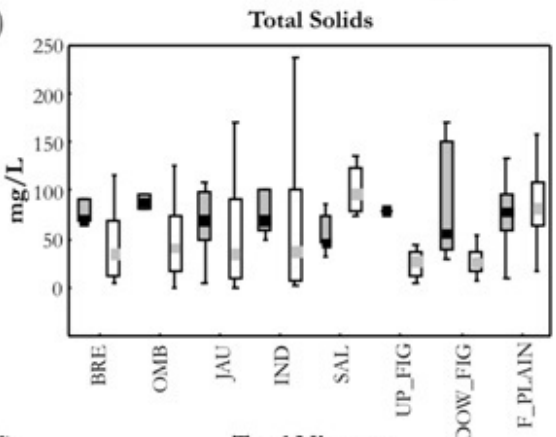

1)

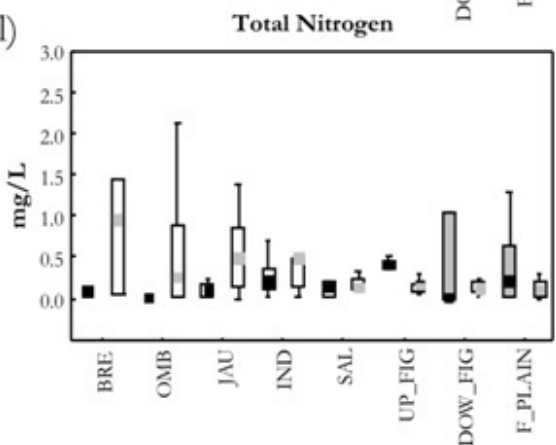

Legend: BRE, OMB, JAU, IND, SAL, UP_FIG, DOW_FIG and

F PLAIN-colletion points between all six hydreletric plants in Tauru River.

自 Natural (median, 25\%-75\%) 自Altered (median, 25\%-75\%)

Figure 2. Longitudinal variation in water quality of the Jauru River, in the natural (1990 to 2002) and altered (2003 to 2013$)$ phases. 
Table 2. Effect of hydropower plants on the water quality of the Jauru River, between the natural (1990 to 2002) and altered (2003 to 2013) phases, evaluated by the Kruskal-Wallis test (significant values in bold, where $\mathrm{p}$ is the significance of the test; $\mathrm{N}$ is the number of samples collected; Nat is the number of samples in the natural phase, Alt is the number of samples in the altered phase; shaded cells were disregarded in the analysis because fewer than four samples were available for one of the phases or because there were no measurements).

\begin{tabular}{|c|c|c|c|c|c|c|c|c|c|c|c|c|c|c|c|c|c|}
\hline \multirow{3}{*}{ Parameters } & \multicolumn{17}{|c|}{ Colection Points } \\
\hline & & \multicolumn{2}{|c|}{ BRE } & \multicolumn{2}{|c|}{ OMB } & \multicolumn{2}{|c|}{ JAU } & \multicolumn{2}{|c|}{ IND } & \multicolumn{2}{|c|}{ SAL } & \multicolumn{2}{|c|}{ UP_FIG } & \multicolumn{2}{|c|}{ DOW_FIG } & \multicolumn{2}{|c|}{ F_PLAIN } \\
\hline & & Nat & Alt & Nat & Alt & Nat & Alt & Nat & Alt & Nat & Alt & Nat & Alt & Nat & Alt & Nat & Alt \\
\hline Water & $\mathrm{p}$ & \multicolumn{2}{|c|}{0.651} & \multicolumn{2}{|c|}{0.962} & \multicolumn{2}{|c|}{0.300} & \multicolumn{2}{|c|}{0.352} & \multicolumn{2}{|c|}{0.140} & \multicolumn{2}{|c|}{-} & \multicolumn{2}{|c|}{0.330} & \multicolumn{2}{|c|}{0.035} \\
\hline temperature & $\mathrm{N}$ & 4 & 15 & 2 & 25 & 11 & 40 & 12 & 25 & 5 & 4 & 5 & 18 & 7 & 12 & 25 & 40 \\
\hline \multirow[t]{2}{*}{$\mathrm{pH}$} & $\mathrm{p}$ & \multicolumn{2}{|c|}{0.547} & \multicolumn{2}{|c|}{0.676} & \multicolumn{2}{|c|}{0.101} & \multicolumn{2}{|c|}{0.027} & \multicolumn{2}{|c|}{0.230} & \multicolumn{2}{|c|}{0.156} & \multicolumn{2}{|c|}{0.246} & \multicolumn{2}{|c|}{0.428} \\
\hline & $\mathrm{N}$ & 4 & 15 & 2 & 25 & 11 & 40 & 12 & 25 & 5 & 3 & 5 & 18 & 8 & 12 & 25 & 60 \\
\hline Collor & $\mathrm{p}$ & & & & & & & & & 0. & & & & & & 0.0 & \\
\hline & $\mathrm{N}$ & 3 & 10 & 2 & 19 & - & 32 & 2 & 17 & 2 & 2 & - & 16 & - & 10 & 23 & 60 \\
\hline Turbidity & $\mathrm{p}$ & & & & & & & & & & & & & 0. & & $0 .($ & \\
\hline & $\mathrm{N}$ & 4 & 15 & 2 & 25 & 11 & 40 & 11 & 23 & 5 & 4 & 5 & 18 & 7 & 12 & 25 & 60 \\
\hline Electrical & $\mathrm{p}$ & & & & & & & & & & & & & 0. & & 0.1 & \\
\hline condutivity & $\mathrm{N}$ & 4 & 15 & 2 & 25 & 11 & 40 & 12 & 25 & 2 & 2 & - & 16 & 7 & 12 & 20 & 53 \\
\hline COD & $\mathrm{p}$ & & & & & & & & & & & & & & & & \\
\hline & $\mathrm{N}$ & 4 & 11 & 2 & 25 & 10 & 39 & 11 & 24 & 2 & 2 & - & 16 & 4 & 12 & 25 & 38 \\
\hline BOD & $\mathrm{p}$ & & & & & & & & & 0. & & & & 0.8 & & 0.2 & \\
\hline & $\mathrm{N}$ & 3 & 13 & 2 & 19 & 9 & 37 & 11 & 22 & 5 & 4 & 5 & 18 & 4 & 12 & 23 & 60 \\
\hline Dissolved oxygen & $\mathrm{p}$ & & & & & & & & & 0. & & & & 0. & & 0.2 & \\
\hline & $\mathrm{N}$ & 4 & 12 & 2 & 24 & 8 & 38 & 9 & 23 & 5 & 4 & 5 & 18 & 4 & 10 & 25 & 57 \\
\hline Total solids & $\mathrm{p}$ & & & & & & & & & & & & & 0. & & 0.4 & \\
\hline & $\mathrm{N}$ & 3 & 13 & 2 & 19 & 8 & 39 & 9 & 24 & 5 & 4 & 5 & 18 & 6 & 10 & 22 & 60 \\
\hline Suspended solids & $\mathrm{p}$ & & & & & & & & & & & & & & & 0. & \\
\hline & $\mathrm{N}$ & 4 & 13 & 2 & 20 & 8 & 39 & 9 & 24 & 5 & 4 & 3 & 18 & 5 & 10 & 2 & 29 \\
\hline Total phosphorus & $\mathrm{p}$ & & & & & & & & & & & & & & & 0.0 & \\
\hline & $\mathrm{N}$ & 4 & 15 & 2 & 25 & 11 & 40 & 12 & 25 & 5 & 4 & 5 & 18 & 3 & 12 & 23 & 60 \\
\hline Total nitrogen & $\mathrm{p}$ & & & & & & & & & & & & & & & 0.4 & \\
\hline & $\mathrm{N}$ & 4 & 15 & 2 & 25 & 11 & 39 & 12 & 24 & 5 & 4 & 5 & 18 & 3 & 12 & 8 & 19 \\
\hline
\end{tabular}

construction of the hydroelectric plants, these values increased at all sites, but were not significantly different (Figure 2; Table 2).

Turbidity presented medians of below 12 NTU both before and after the construction of the hydroelectric plants; this is considered low (Figure 2). Upstream of the third and fourth hydropower plants (JAU and IND), there was a significant reduction in turbidity between the two phases, natural and altered, and in SAL there was an increase in this parameter. At these three sites, variation in the data set between the two phases was significant (Table 2).

Electrical conductivity was significantly lower in the altered phase in relation to the natural phase only downstream of the Jauru HPP (IND), where the water outlet from the dam is at the surface. In general, values were low in the upper and middle parts of the river, with increases in the floodplain (F_PLAIN) (Figure 2; Table 2). Conductivity along the Jauru River was low, with a low median variation and no significant difference between the natural and altered phases, except in F_PLAIN (Figure 2; Table 2).

The low BOD values observed before and after the installation of the hydroelectric dams indicate a low concentration of labile organic matter in the waters of the Jauru River (Table 2). In JAU, IND and UP_FIG, BOD was significantly different between the natural and altered phases. The results for these two parameters reflect good water oxygenation in the Jauru River, with OD concentrations always above $5.0 \mathrm{mg} / \mathrm{L}$ from BRE to DOW_FIG, favored also by the presence of natural rapids and slopes along the river, as well as by water swirling when passing through the turbines of the plants. In F_PLAIN (floodplain), 82\% of the samples had concentrations above $5.0 \mathrm{mg} / \mathrm{L}$, and the lowest results at this site were recorded during the flood period (Table 2).

The concentrations of total phosphorus were, in general, relatively low in the Jauru River, with $85 \%$ of the samples showing values less than or equal to $0.1 \mathrm{mg} / \mathrm{L}$, with some peaks in the rainy period in JAU, IND and F_PLAIN (Figure 2).

Total solids concentrations were lower than $100 \mathrm{mg} / \mathrm{L}$ in $75 \%$ of the samples, correlating with the low turbidity results. In UP_FIG and DOW_FIG, the medians were significantly lower in the altered phase than in the natural phase.

Samples suggested that there was retention of suspended solids from IND to F_PLAIN; however, the analysis of this parameter was impaired due to the small number of samples available from before the construction of the plants (two samples taken in 1995) which were collected at the start of the rainy period, when the concentration tends to be higher.

In the analysis of the effect of HPP on the change in water quality, it was observed that among the twelve parameters evaluated, 
nine showed significant alterations in at least one HPP (Table 2). Turbidity, followed by BOD, were the parameters most affected by HPP, verified in JAU, IND, SAL and F_PLAIN. The highest number of altered parameters was observed downstream of the Jauru HPP (IND).

Only at UP_FIG was there a significant difference in phosphorus concentration, with a reduction after Salto SHPP, whose water outlet is between the surface and the middle of the dam. In general, there was a decrease in total phosphorus between JAU and SAL and an increase in UP_FIG, upstream of the Figueirópolis SHPP, which can be attributed to the Sangue Stream. With regard to total nitrogen, it was observed that only downstream of the Ombreiras SHPP (JAU), whose water inlet is at the bottom of the reservoir, was there a significant increase in nitrogen concentration in the altered phase in relation to the natural phase (Table 2).

As for the magnitude of the changes, out of the 12 parameters evaluated, eight presented alterations of above $50 \%$ between the natural and altered phases, with reductions in turbidity, total solids (except SAL) and phosphorus (except UP_FIG) and increases in color and COD in SAL and BOD and total nitrogen in JAU and IND (Table 3).

The morphological and hydraulic characteristics accumulated in three sections of the Jauru River (OMB-SAL; OMB-UP_FIG and OMB-DOW_FIG) were correlated with the rate of change of some water quality parameters (Table 4). Between the OMB-SAL stretches, turbidity, total phosphorus, BOD, COD, electrical conductivity and suspended solids had a correlation of above 0.7 for the area and/or flooded extension. However, in cumulative terms, only water temperature and total nitrogen had a strong to moderate correlation for the area, flooded extension and accumulated WRT between OMB-SAL. In the sections between OMB-UP_FIG and between OMB-DOW_FIG, none of the water quality parameters presented a strong correlation with these characteristics in a cumulative way (except COD between OMB-DOW_FIG for accumulated flooded area).

Dissolved oxygen presented only a moderate correlation (0.40) with the flooded length between OMB-SAL, however, when a comparison was made between the altered water temperature and OD between OMB and SAL, the value was 0.95 , showing a strong correlation between these two parameters. It was observed that water temperature varied with flooded area, flooded longitudinal length and WRT accumulated, which explains why the effects for OD also seem to be cumulative for the hydropower plants in sequence between OMB-SAL.

\section{DISCUSSION}

In the general characterization of water quality of the Jauru River, low turbidity, color and solids concentration results were obtained, reflecting the reduced sediment load transported by this river. This characteristic corroborates the studies of Souza, Sousa and Silva Andrade (2012), who found that sediment loads throughout the water column (except bottom trawling) ranged from 0.400 to $10.300 \mathrm{mg} / \mathrm{L}$ in the upper course, between $18.100 \mathrm{mg} / \mathrm{L}$ and 21.600 in the middle course and $30.500 \mathrm{mg} / \mathrm{L}$ in the low reach, consistent with the low erosive potential of the soils of the basin, even under intense use for livestock activity (FIGUEIREDO, 2007; MOREIRA; VASCONCELOS, 2007; ANDRADE et al., 2012). Analysis of the results was limited by this low concentration, together with the short WRT of the reservoirs, which is a factor that keeps these parameters little altered along the river, particularly color, which is related to the concentration of smaller particles that require more time to settle and to be retained in the reservoirs.

In relation to the electrolytic poverty of this river, demonstrated by the low values of electrical conductivity in the upper and middle stretches, a slight acidity of the water was also observed, reflecting the weak or nonexistent magnetic attraction in the soils of the basin and the absence of calcareous formations (FIGUEIREDO, 2007; MOREIRA; VASCONCELOS, 2007). In tropical regions, the values of electrical conductivity in aquatic environments are usually related to the geochemical characteristics of the region where they are located and to climatic conditions (dry and rainy season; PETRUCIO; BARBOSA; THOMAZ, 2005), especially in rivers whose trophic condition is less affected by anthropogenic

Table 3. Rate of change of the medians of water quality ( $\%$ ) parameters for the Jauru River (values in bold are above $50 \%$, a negative percentage means a decrease, but no negative increase in median between natural and altered phases; shaded cells were disregarded in the analysis because fewer than four samples were available for one of the phases or because there were no measurements).

\begin{tabular}{|c|c|c|c|c|c|c|c|c|}
\hline \multirow{2}{*}{ Parameters } & \multicolumn{8}{|c|}{ Collection Points } \\
\hline & BRE & OMB & JAU & IND & SAL & UP_FIG & DOW_FIG & F_PLAIN \\
\hline Water temp. & -0.5 & 1.3 & 2.1 & 4.2 & 6.8 & 2.3 & 1.9 & 2.8 \\
\hline $\mathrm{pH}$ & 6.0 & -0.4 & -6.6 & -5.5 & -3.4 & -1.8 & -5.8 & 0.5 \\
\hline Collor & 86.8 & 83.1 & & 4.0 & 61.6 & & & 26.8 \\
\hline Turbidity & -117.5 & 17.5 & -100.0 & -255.8 & 67.7 & 35.0 & -100.0 & 21.7 \\
\hline Electric conductivity & 49.6 & 49.1 & -41.3 & -28.9 & -4.0 & & -28.5 & 16.3 \\
\hline COD & 27.3 & 71.6 & -1.6 & 11.7 & 55.1 & & -85.5 & 55.0 \\
\hline BOD & 52.6 & 55.0 & 52.6 & 52.6 & 0.00 & -111.1 & 0.0 & 0.0 \\
\hline Dissolved oxygen & -10.2 & -7.4 & -10.3 & -8.1 & -37.6 & -1.2 & 2.4 & -5.1 \\
\hline Total solids & -100.0 & -115.8 & -100.0 & -89.1 & 51.5 & -185.7 & -113.2 & 8.7 \\
\hline Suspended solids & 40.0 & 54.0 & -10.0 & -400.0 & -27.5 & -117.7 & -41.1 & -177.2 \\
\hline Total phosphorus & -15.0 & 32.1 & -100.0 & -97.9 & -16.1 & 50.0 & -10.0 & 4.2 \\
\hline Total nitrogen & 90.0 & 96.6 & 79.5 & 57.2 & 1.8 & -175.4 & 85.3 & -112.0 \\
\hline
\end{tabular}


Table 4. Squared Pearson correlation coefficient $\left(\mathrm{R}^{2}\right)$ between the morphological and hydraulic characteristics of the hydropower plants and the ratio of the medians of water quality parameters between the sites OMB and SAL, OMB and UP_FIG, OMB and DOW_FIG in the natural and altered phases, in the Jauru River. Shaded cells indicate correlations above 0.7, and in bold between 0.69 and 0.4.

\begin{tabular}{|c|c|c|c|c|c|c|c|}
\hline Parameters & Accumulation & $\begin{array}{l}\text { Flooded } \\
\text { area }\end{array}$ & $\begin{array}{l}\text { Accumulated } \\
\text { flooded area }\end{array}$ & $\begin{array}{l}\text { Lenght } \\
\text { flooded }\end{array}$ & $\begin{array}{l}\text { Accumulated } \\
\text { lenght flooded }\end{array}$ & WRT & $\begin{array}{c}\text { Accumulated } \\
\text { WRT }\end{array}$ \\
\hline \multirow[t]{3}{*}{ Turbidity } & $\mathrm{OMB}$ to SAL & 0.92 & 0.05 & 0.76 & 0.04 & 0.56 & 0.09 \\
\hline & OMB to UP_FIG & 0.83 & 0.00 & 0.72 & 0.00 & 0.61 & 0.01 \\
\hline & OMB to DOW_FIG & 0.02 & 0.02 & 0.30 & 0.01 & 0.48 & 0.04 \\
\hline \multirow{3}{*}{$\begin{array}{l}\text { Total } \\
\text { phosphorus }\end{array}$} & $\mathrm{OMB}$ to SAL & 0.84 & 0.17 & 0.97 & 0.19 & 0.18 & 0.31 \\
\hline & OMB to UP_FIG & 0.57 & 0.00 & 0.71 & 0.00 & 0.14 & 0.02 \\
\hline & OMB to DOW_FIG & 0.00 & 0.01 & 0.09 & 0.01 & 0.39 & 0.00 \\
\hline \multirow{3}{*}{$\begin{array}{l}\text { Water } \\
\text { temperature }\end{array}$} & $\mathrm{OMB}$ to $\mathrm{SAL}$ & 0.00 & 0.84 & 0.00 & 0.84 & 0.05 & 0.73 \\
\hline & OMB to UP_FIG & 0.00 & 0.31 & 0.23 & 0.08 & 0.20 & 0.21 \\
\hline & OMB to DOW_FIG & 0.07 & 0.00 & 0.05 & 0.00 & 0.07 & 0.04 \\
\hline \multirow[t]{3}{*}{$\mathrm{pH}$} & OMB to SAL & 0.65 & 0.06 & 0.12 & 0.42 & 0.84 & 0.36 \\
\hline & OMB to UP_FIG & 0.02 & 0.51 & 0.04 & 0.52 & 0.86 & 0.11 \\
\hline & OMB to DOW_FIG & 0.00 & 0.11 & 0.00 & 0.14 & 0.80 & 0.46 \\
\hline \multirow{3}{*}{$\begin{array}{l}\text { Biochemical } \\
\text { Oxygen } \\
\text { Demand }\end{array}$} & $\mathrm{OMB}$ to SAL & 0.17 & 0.39 & 0.12 & 0.42 & 0.22 & 0.32 \\
\hline & OMB to UP_FIG & 0.02 & 0.51 & 0.93 & 0.52 & 0.23 & 0.32 \\
\hline & OMB to DOW_FIG & 0.00 & 0.11 & 0.00 & 0.21 & 0.10 & 0.19 \\
\hline \multirow{3}{*}{$\begin{array}{l}\text { Dissolved } \\
\text { oxygen }\end{array}$} & $\mathrm{OMB}$ to $\mathrm{SAL}$ & 0.17 & 0.36 & 0.12 & 0.40 & 0.20 & 0.30 \\
\hline & OMB to UP_FIG & 0.12 & 0.02 & 0.06 & 0.03 & 0.04 & 0.06 \\
\hline & OMB to DOW_FIG & 0.25 & 0.12 & 0.25 & 0.07 & 0.18 & 0.02 \\
\hline \multirow[t]{3}{*}{ Total nitrogen } & OMB to SAL & 0.00 & 0.75 & 0.00 & 0.77 & 0.06 & 0.67 \\
\hline & OMB to UP_FIG & 0.00 & 0.60 & 0.01 & 0.61 & 0.17 & 0.41 \\
\hline & OMB to DOW_FIG & 0.08 & 0.00 & 0.09 & 0.03 & 0.24 & 0.04 \\
\hline Chemical & $\mathrm{OMB}$ to SAL & 0.76 & 0.06 & 0.93 & 0.08 & 0.97 & 0.17 \\
\hline Oxygen & OMB to UP_FIG & 0.76 & 0.06 & 0.93 & 0.08 & 0.97 & 0.17 \\
\hline Demand & OMB to DOW_FIG & 0.90 & 0.75 & 0.98 & 0.69 & 0.86 & 0.65 \\
\hline \multirow{3}{*}{$\begin{array}{l}\text { Electric } \\
\text { conductivity }\end{array}$} & $\mathrm{OMB}$ to SAL & 0.63 & 0.29 & 0.82 & 0.33 & 0.75 & 0.48 \\
\hline & OMB to UP_FIG & 0.63 & 0.29 & 0.82 & 0.33 & 0.75 & 0.48 \\
\hline & OMB to DOW_FIG & 0.21 & 0.18 & 0.44 & 0.25 & 0.67 & 0.40 \\
\hline \multirow[t]{3}{*}{ Total solids } & OMB to SAL & 0.10 & 0.50 & 0.07 & 0.521 & 0.17 & 0.42 \\
\hline & OMB to UP_FIG & 0.04 & 0.00 & 0.01 & 0.00 & 0.00 & 0.03 \\
\hline & OMB to DOW_FIG & 0.03 & 0.00 & 0.03 & 0.00 & 0.01 & 0.00 \\
\hline \multirow{3}{*}{$\begin{array}{l}\text { Suspended } \\
\text { solids }\end{array}$} & $\mathrm{OMB}$ to $\mathrm{SAL}$ & 0.72 & 0.38 & 0.49 & 0.33 & 0.18 & 0.37 \\
\hline & OMB to UP_FIG & 0.71 & 0.28 & 0.47 & 0.24 & 0.14 & 0.33 \\
\hline & OMB to DOW_FIG & 0.00 & 0.00 & 0.03 & 0.02 & 0.03 & 0.08 \\
\hline
\end{tabular}

WRT $=$ Water Retention Time.

interference, as observed in the Jauru River. The increase in conductivity and, consequently, $\mathrm{pH}$ level in the lower part of the river is due to the floodable areas, which contribute ions to the main channel (JUNK; BAYLEY; SPARKS, 1989) adding to the natural increase in ions from upstream to downstream.

Waters diluted by domestic or industrial effluents in the Jauru River are inexpressive, reflecting low concentrations of BOD, COD, nitrogen and phosphorus, which indicates a reduced potential for eutrophication in reservoirs and tendency to oligotrophy along the river, as mentioned above. With respect to COD, the results would probably be less than $20 \mathrm{mg} / \mathrm{L}$ (limit of detection), except in F_PLAIN, where the higher results and difference between the natural and altered phases reflect the influence of the floodplain, whose connection with the Jauru River favors an increase in oxidizable organic and inorganic substances, as indicated also by the values for electrical conductivity.

The low BOD values found before and after the installation of the HPP indicate a low concentration of labile organic matter in the waters of the Jauru River, for the same reasons mentioned in relation to COD. Concentrations of nitrogen and phosphorus were similarly low in both phases, indicating a tendency to oligotrophy, and good levels of water oxygenation, with concentrations almost always above $5.0 \mathrm{mg} / \mathrm{L}$, were also maintained. These DO results are related to the presence of natural rapids and slopes along the river, as well as to the water swirling when passing through the turbines of the plants. On the other hand, in F_PLAIN (floodplain), the lower DO $(<5.0 \mathrm{mg} / \mathrm{L}$ in $18 \%$ of samples $)$ observed in the rainy season reflects the organic matter input from the flooded areas by the Jauru River at this time of the year, as also indicated by the results for COD and electrical conductivity.

In general, these conditions may have minimized the response to changes caused by hydropower plants, and the limited availability of data from before the installation of such developments made it more difficult to measure impacts. However, even considering these aspects, it was possible to identify some patterns of water quality change caused by the six hydroelectric plants in the Jauru 
River, both individual and cumulative. It is important to mention that inferences about the effects of hydroelectric developments on water quality using the available data should be made using appropriate statistical analysis. The Kruskal-Wallis test used here to evaluate whether water quality samples between the monitoring stations were from different populations allows us to assume that the samples are random and that cases for each group are independent, since the samples from the same fluvial system are from different dates.

The patterns of water quality change observed in this study can be understood on the basis of two ecological river concepts: the River Continuum Concept (RCC) and the Serial Discontinuity Concept (SDC). The first emphasizes the longitudinal links in a river, combining stochastic and deterministic, abiotic and biotic aspects (HUMPHRIES; KECKEIS; FINLAYSON, 2014). SDC can be applied to explain the longitudinal disconnection of river continuum (RCC) caused by an anthropic disturbance, and is usually applied to rivers with hydroelectric dams to analyze the effect of a series of reservoirs on a river (CARLUER et al., 2016). Disturbances in river continuum caused by impoundments lead to changes in biotic and abiotic processes downstream, changing not only the hydrological regime, but also the thermal, nutrient, sediment regimes and water chemistry (POFF et al., 1997; OLDEN; NAIMAN, 2010). These changes depend on the position of the reservoirs in the river basin, as well as the proximity between two or more dams (CARLUER et al., 2016). This was evidenced in this study, where all the reservoirs, located in the upper and middle stretches of the river, close to each other (between JAU and DOW_FIG), within in a segment of about $45 \mathrm{~km}$, presented alterations in relation to the natural phase (even disregarding $\mathrm{OMB}$ due to the low number of samples).

The parameters that showed significant changes downstream of each reservoir in this section of the river, and therefore its discontinuity in relation to the natural continuum phase, were: turbidity, BOD and total nitrogen in the Ombreiras SHPP (JAU); $\mathrm{pH}$, electrical conductivity, turbidity, BOD and suspended solids in Jauru HPP (IND); turbidity in Indiavaí SHPP; BOD, total solids and total phosphorus in Salto SHPP; and total solids in Figueirópolis SHPP. In the floodplain (F_PLAIN), turbidity alteration was observed.

The distance between the reservoirs and along the river determines whether it is possible to minimize the temporal variability of the physical-chemical quality of the water in the long run (CARLUER et al., 2016). Specifically in relation to the floodplain, the long stretch between DOW_FIG and F_PLAIN (90 km) implies caution in stating that the changes observed in F_PLAIN (Porto Limão) may have been caused solely by the operation of the upstream plants. At this site, the only significant changes in the entire data set were observed, between the natural and altered phases, for water temperature and turbidity. In terms of percentage change in median, COD increase and expressive reduction of suspended solids and total nitrogen were observed.

Junk et al. (2011) indicate that in the Pantanal plain both annual and multiannual variations occur, that is, besides the variation between drought and flood within the period of twelve months, periods of drier years and wetter years occur, which drastically affect aquatic and terrestrial vegetation.
In the floodplain, the meandering of the Jauru River is quite expressive, and the river loses transport capacity and increases the amount of sediment deposited on the banks and plain; the river reaches the floodable areas of the Pantanal, forming a kind of fan, flowing into bays, floodplain lakes or oxbow lakes, or spreading into the plain during the flood season through corixos and ebb tides, which are separated by terraces and marginal levees with several levels of accumulation, both ancient and recent (SOUZA; SOUSA; SILVA ANDRADE, 2012). These characteristics demonstrate the diversity of aquatic ecosystems, which together with the annual and pluriannual variability of the plains, most likely imply the occurrence of sediment deposition-erosion dynamics and a relationship between aquatic and terrestrial environments that may cause changes in water quality over the years, making it impossible to identify modifications caused exclusively by upstream hydropower plants.

On the other hand, at BRE, upstream of all the hydroelectric plants, no significant change was detected for the whole data set, only percentage changes in the median, with increases in color and total nitrogen and a reduction in turbidity, indicating possible changes in the uses of soil and water in the headwaters region, probably related to agricultural activity.

It should be noted that knowledge of the particular characteristics of each reservoir cascade, such as morphology, presence of streams, human activities, and type of dam operation, is essential to understanding the processes in different reservoirs as well as over the entire cascade (SANTOS et al., 2016), including the WRT.

Although the dams installed in the Jauru River have a low WRT, in which is 10 days between OMB and SAL, reducing the speed of water flow and retaining sediment (indicated by turbidity) and phosphorus. The retention of phosphorus also indicated that the reservoirs with higher WRT had the highest percentages of reduction of this nutrient and vice versa, but downstream of UP_FIG, there was an increase in the phosphorus concentration between the natural and altered phases. As for nitrogen, this pattern was not observed; a reduction occurred only in UP_FIG and F_PLAIN, with an increase downstream of the others (between JAU and SAL). A large proportion of the total phosphorus load that enters reservoirs is transported as particles, in association with bottom or suspended sediments (FONSECA et al., 2011), and therefore its retention is more easily detected than nitrogen in reservoirs (DONALD et al., 2015; MAAVARA et al., 2015).

On the other hand, other studies have shown that for phosphorus and nitrogen there is no clear pattern of retention or export downstream. Fantin-Cruz et al. (2015a) reported a reduction in these nutrients, while Oliveira (2016) reported an increase, as well as indicating a reduction in nitrate and an elevation in total nitrogen, as observed in this study. In addition, several studies demonstrate that reservoirs located further downstream, near the exutory, are more efficient in their retention of nitrogen than those located upstream, and that numerous small reservoirs are more efficient than a single large reservoir (CARLUER et al., 2016), corroborating what was verified downstream of Salto SHHP (UP_FIG) and Figueirópolis (DOW_FIG, in this case with only three samples in the natural phase), where there was 
an expressive reduction in nitrogen, indicated by the percentage variation in the median.

Control of WRT by reservoir operation can determine the magnitude of changes in water quality; however, this does not always imply that the lower the WRT the lower the impact (FANTIN-CRUZ et al., 2015b). The average WRT of the six hydroelectric plants per sampling site can be represented as follows: DOW_FIG $>$ JAU $>$ IND $>$ UP_FIG $>$ SAL $>$ OM. These differences in WRT did not imply changes of the same magnitude or in the number of altered water quality parameters, except for the retention of phosphorus between OMB-SAL, as mentioned above. This indicates that in addition to WRT, flooded area, location in the river continuum, distance between dams and height of the water inlet are factors that together cause changes in water quality and longitudinal discontinuity in each dam and cumulatively. These factors can also affect biotic communities in different ways, as shown by Santos et al. (2018), whose analysis of different ecological assemblages found that physical-chemical changes in a reservoir cascade were the most important in explaining phytoplankton, while spatial variables such as longitudinal position and distance from nearest reservoirs have a more pronounced effect on the fish assemblage.

With respect to the height of the water inlet, the formation of a lake, even if small, increases exposure to solar radiation, causing surface heating, and reservoirs with superficial water outlets tend to release warmer water in relation to the abstraction at the bottom of the reservoir (FANTIN-CRUZ et al., 2015a,b; CRUZ, 2018). In the present study, water temperature tended to increase in relation to surface area exposed to solar radiation in all the reservoirs along the section. Individually, this was not significant; the only significant difference was between OMB and SAL, where accumulated flooded area, length and WRT presented a positive correlation $(>0.7)$ with the median water temperature, indicating a cumulative effect of heat on the four reservoirs located upstream of these sites, together with the superficial water inlet in JAU and IND. As a consequence, the increase in temperature moderately influenced the reduction of dissolved oxygen for the area and accumulated length in this section of the Jauru River, where an area of 343.9 ha is flooded within $17.98 \mathrm{~km}$ of the river.

According to Girard (2002), water temperature changes as flow is retarded by dams. If the dam is shallow the temperature in the river will tend to rise, and consequently the dissolved oxygen content may decrease. Despite the lack of data on the average depth of the reservoirs in the Jauru River, it is known empirically that they are relatively shallow, with the exception of the Jauru HPP (maximum 35m; FIGUEIREDO, 2007). The increase in temperature downstream of small dams was also observed by Mbaka and Wanjiru Mwaniki (2015). It is worth noting that temperature is considered a key factor in the evaluation and management of impacts caused by reservoirs, and directly influences the ecology and physiology of organisms (OLDEN; NAIMAN, 2010).

In addition to water temperature, the cumulative effect of the cascade reservoirs in the Jauru River was also shown in the results for total nitrogen and COD in relation to the accumulated flooded area and length, with a percentage increase in the median of these two parameters between OMB-SAL. When the reservoirs are close, there is more evidence for the cumulative effect, given the extent of the individual effects (disturbance intensity) that do not allow a return to the initial status (CARLUER et al., 2016).

Another constructive characteristic that causes water quality alteration is the depth of water exits in reservoirs with respect to turbidity. In those where exits are at the reservoirs' surface (JAU and IND), downstream turbidity reduction was observed and in those where water flows out from the lower part of the reservoir, turbidity reduction upstream (SAL) was observed. This is due to the relation of this parameter to the concentration of larger particles, which settle more quickly, presenting lower concentrations at the surface and higher at the bottom of reservoirs.

\section{CONCLUSIONS}

The water quality of the Jauru River in general was characterized by low concentrations of electrolytes and slightly acidic $\mathrm{pH}$, oligotrophy, reduced values of $\mathrm{BOD}, \mathrm{COD}$, color, turbidity and solids and good oxygenation. While these general conditions were maintained over the two phases studied, we verified the occurrence of change in the pattern of variation of the physical and chemical conditions evaluated, mainly between the second and the fifth hydroelectric reservoir. This change, which implies discontinuity in the longitudinal gradient, was indicated by nine out of the twelve parameters measured in this stretch of the Jauru River, downstream of each individual reservoir and/or cumulatively. In the floodplain, the observed changes could not be clearly attributed to the hydroelectric projects located upstream.

The constructive characteristics of the hydropower plants, especially water inlet height, water retention time and flooded area, as well as the proximity between two or more impoundments, are factors that influenced the observed changes.

It is also worth mentioning that the difficulty of obtaining data from before the construction of the six hydroelectric plants in the Jauru River and the gaps in available data show that licensing processes of all plants were not integrated or based on assessment across the whole basin. This situation seems to be recurring in several tributaries of the Pantanal, where more than 100 new projects are planned, either isolated or in cascade, indicating the need for studies that consider the basin in an integrated way, and for the collection of more consistent data before these impoundments are implemented. The constructive characteristics of the hydroelectric plants and their location along the river should also be considered, as important aspect in the processes of environmental licensing for these future plants, or even, in some cases, to avoid them from being built at all as planned.

\section{REFERENCES}

ANDRADE, L. N. P.; RITELA, A.; PERETTTO, A.; SOUZA, C. A.; MATOS, E. H.; SOUSA, J. B.; ARAÚJO, R. M.; SANTOS, Z. G.; SOUZA, M. A.; MEIRELES, Z. G. Uso e ocupação da bacia hidrográfica do rio Jauru. In: SOUZA, C. A.; SOUSA, J. B.; ANDRADE, L. N. P. S. (Ed.). Bacia Hidrográfica do rio Jauru, Mato Grosso: dinâmica espacial e impactos associados. São Carlos: RiMa, 2012. p. 81-120. 
APHA - AMERICAN PUBLIC HEALTH ASSOCIATION. Standard methods for the examination of water and wastewater. 21st ed. Washington: APHA, 2005.

APHA - AMERICAN PUBLIC HEALTH ASSOCIATION. Standard methods for the examination of water and wastewater. 22nd ed. Washington: APHA, 2012.

BRASIL. CONAMA - CONSELHO NACIONAL MEIO AMBIENTE. Resolução CONAMA no 357, de 18 de março de 2005. Dispõe sobre a classificação dos corpos de água e diretrizes ambientais para o seu enquadramento, bem como estabelece as condições e padrões de lançamento de efluentes, e dá outras providências. Diário Oficial [da] República Federativa do Brasil, Brasília, DF, 18 mar. 2005.

BRASIL. Ministério de Minas e Energia. ANEEL - Agência Nacional de Energia Elétrica. Resolução no 673, de 4 de agosto de 2015. Estabelece os requisitos e procedimentos para a obtenção de outorga de autorização para exploração de aproveitamento de potencial hidráulico com características de Pequena Central Hidrelétrica - PCH. Diário Oficial [da] República Federativa do Brasil, Brasília, DF, 2 set. 2015. 14 p.

CALHEIROS, D. F.; OLIVEIRA, M. D. O rio Paraguai e sua planície de inundação: o Pantanal Mato-Grossense. Ciência \& Ambiente, v. 41, p. 113-130, 2011.

CARDOSO, O.; ROCHA, N.; XAVIER, R.; VALDUGA, E.; DISCONZI, G.; RADTKE, L.; CRUZ, R. Analysis of environmental fragility in the basin of rio Pardo - RS an integrated environmental assessment. Revista Brasileira de Recursos Hidricos., v. 20, n. 2, p. $507-$ 522, 2015. http://dx.doi.org/10.21168/rbrh.v20n2.p507-522.

CARLUER, N.; BABUT, M.; BELLIARD, J.; BERNEZ, I.; BURGER-LEENHARDT, D.; DORIOZ, J. M.; DOUEZ, O.; DUFOUR, S.; GRIMALDI, C.; HABETS, F.; LE BISSONNAIS, Y.; MOLÉNAT, J.; ROLLET, A. J.; ROSSET, V.; SAUVAGE, S.; USSEGLIO-POLATERA, P.; LEBLANC, B. Cumulative impact of reservoirs on the aquatic environment. joint scientific assessment: summary report. France: Irstea/Inra/Onema, 2016. 82 p.

CRUZ, R. F. Impactos de pequenas centrais hidrelétricas com diferentes arranjos na bacia do alto São Lourenço. 2018. 151 f. Tese (Doutorado em Física Ambiental) - Universidade Federal de Mato Grosso, Cuiabá, 2018.

DEITCH, M. J.; MERENLENDER, A. M.; FEIRER, S. T. Cumulative effects of small reservoirs on streamflow in northern coastal California catchments. Water Resources Management, v. 57, p. 5101-5118, 2013.

DONALD, D. B.; PARKER, B. R.; DAVIES, J.-M.; LEAVITT, P. R. Nutrient sequestration in the Lake Winnipeg watershed. Journal of Great Lakes Research, v. 41, n. 2, p. 630-664, 2015. http:/ /dx.doi. org/10.1016/j.jglr.2015.03.007.

FANTIN-CRUZ, I.; PEDROLLO, O.; GIRARD, P.; ZEILHOFER, P.; HAMILTON, S. K. Effects of a diversion hydropower facility on the hydrological regime of the Correntes River, a tributary to the Pantanal floodplain, Brazil. Journal of Hydrology, v. 531, p. 810-820, 2015a. http://dx.doi.org/10.1016/j.jhydrol.2015.10.045.

FANTIN-CRUZ, I.; PEDROLLO, G.; GIRARD, P.; ZEILHOFER, P.; HAMILTON, S. K. Changes in river water quality caused by a diversion hydropower dam bordering the Pantanal floodplain. Hydrobiologia, v. 768, n. 1, p. 223-238, 2015b. http://dx.doi. org/10.1007/s10750-015-2550-4.

FEARNSIDE, P. M. Tropical hydropower in the Clean Development Mechanism: Brazil's Santo Antônio Dam as an example of the need for change. Climatic Change, v. 131, n. 4, p. 575-589, 2015. http://dx.doi.org/10.1007/s10584-015-1393-3.

FIGUEIREDO, D. M. Padrões liminológicos e do fitoplâncton nas fases de enchimento e estabilização dos reservatórios do APM Manso e AHE Jauru (Estado de Mato Grosso). 2007. 270 f. Tese (Doutorado em Ecologia e Recursos Naturais) - Universidade Federal de São Carlos, São Carlos, 2007.

FONSECA, R.; CANÁRIO, T.; MORAIS, M.; BARRIGA, F. J. A. S. Phosphorus sequestration in Fe-rich sediments from two Brazilian tropical reservoirs. Applied Geochemistry, v. 26, n. 9-10, p. 16071622, 2011. http://dx.doi.org/10.1016/j.apgeochem.2011.04.017.

GIRARD, P. Efeito cumulativo das barragens no Pantanal: mobilização para conservação das áreas úmidas do Pantanal e Bacia do Araguaia. Campo Grande: Instituto Centro Vida, 2002. 28 p. Relatório.

HENNIG, T.; WANG, W.; FENG, Y.; OU, X.; HE, D. Review of Yunnan's hydropower development: comparing small and large hydropower projects regarding their environmental implications and socio-economic consequences. Renewable \& Sustainable Energy Reviews, v. 27, p. 585-595, 2013. http://dx.doi.org/10.1016/j. rser.2013.07.023.

HUMPHRIES, P.; KECKEIS, H.; FINLAYSON, B. The river wave concept: integrating river ecosystem models. Bioscience, v. 64, n. 10, p. 870-882, 2014. http://dx.doi.org/10.1093/biosci/biu130.

JUNK, W. J.; BAYLEY, P. B.; SPARKS, R. E. The flood pulse concept in river-floodplain systems. In: DODGE, D. P. (Ed.). Proceedings of the International Large River Symposium. Ottawa: Department of Fisheries and Oceans, 1989. p. 110-127. (Canadian Special Publishing on Fisheries and Aquatic Sciences, 106).

JUNK, W. J.; CUNHA, C. N.; SILVA, C. J.; WANTZEN, K. M. The Pantanal: a large South American wetland and its position in limnological theory. In: JUNK, W. J.; SILVA, C. J.; CUNHA, C. N.; WANTZEN, K. M. The Pantanal: ecology, biodiversity and sustainable management of a large neotropical seasonal wetland. Sofia: Pensoft, 2011. p. 23-45.

JUNK, W. J.; PIEDADE, M. T. F.; LOURIVAL, R.; WITTMANN, F.; KANDUS, P.; LACERDA, L. D.; BOZELLI, R. L.; ESTEVES, F. A.; NUNES DA CUNHA, C.; MALTCHIK, L.; SCHÖNGART, J.; SCHAEFFER-NOVELLI, Y;; AGOSTINHO, A. A. Brazilian wetlands: their definition, delineation, and classification for research, 
sustainable management, and protection. Aquatic Conservation, v. 24, n. 1, p. 5-22, 2014. http://dx.doi.org/10.1002/aqc.2386.

KIBLER, K. M.; TULLOS, D. D. Reply to comment by Henriette I. Jager and Ryan A. McManamay on "Cumulative biophysical impact of small and large hydropower development in $\mathrm{Nu}$ River, China”. Water Resources Research, v. 50, n. 1, p. 760-761, 2014. http:/ / dx.doi.org/10.1002/2013WR014629.

KUMAR, D.; KATOCH, S. S. Sustainability indicators for run of the river (RoR) hydropower projects in hydro rich regions of India. Renewable \& Sustainable Energy Reviews, v. 35, p. 101-108, 2014. http://dx.doi.org/10.1016/j.rser.2014.03.048.

MAAVARA, T.; PARSONS, C. T.; RIDENOUR, C.; STOJANOVIC, S.; DÜRR, H. H.; POWLEY, H. R.; VAN CAPPELLEN, P. Global phosphorus retention by river damming. Proceedings of the National Academy of Sciences of the United States of America, v. 112, n. 51, p. 15603-15608, 2015. PMid:26644553.

MALVEIRA, V. T. C.; ARAÚJO, J. C.; GÜNTNER, A. Hydrological impact of a high-density reservoir network in the semiarid northeastern Brazil. Journal of Hydrologic Engineering, v. 17, n. 1, p. 109-117, 2012. http://dx.doi.org/10.1061/(ASCE)HE.1943-5584.0000404.

MBAKA, J. G.; WANJIRU MWANIKI, M. A global review of the downstream effects of small impoundments on stream habitat conditions and macroinvertebrates. Environmental Reviews, v. 23, n. 3, p. 257-262, 2015. http:/ /dx.doi.org/10.1139/er-2014-0080.

MOREIRA, M. L. C.; VASCONCELOS, T. N. N. Mato Grosso: solos e paisagens. Cuiabá: Entrelinhas/Seplan. 2007.

MOURA, V.; CARVALHO, L. M. T.; MARTINHAGO, A. Z. Análise temporal da dinâmica de uso e ocupação da Bacia do Alto Paraguai (BAP), estudo de caso sub-bacia do Rio Jauru. In: SIMPÓSIO DE GEOTECNOLOGIAS NO PANTANAL, 2., 2009, Corumbá. Anais... Corumbá: Embrapa Informática Agropecuária/INPE, 2009. p. 916-924.

MOURA, V.; CARVALHO, L. M. T.; PEREIRA, J. A. A. Análise temporal da dinâmica de uso e ocupação da sub-bacia do Rio Jauru. In: SIMPÓSIO BRASILEIRO DE SENSORIAMENTO REMOTO, 15., 2011, Curitiba. Anais... São José dos Campos: INPE, 2011. p. 6968.

NALIATO, D. A. O.; NOGUEIRA, M. G.; PERBICHE-NEVES, G. Discharge pulses of hydroelectric dams and their effects in the downstream limnological conditions: a case study in a large tropical river (SE Brazil). Lakes and Reservoirs: Research and Management, v. 14, n. 4, p. 301-314, 2009. http://dx.doi.org/10.1111/j.14401770.2009.00414.x.

OLDEN, J. D.; NAIMAN, R. J. Incorporating thermal regimes into environmental flows assessments: modifying dam operations to restore freshwater ecosystem integrity. Freshwater Biology, v. 55, n. 1, p. 86-107, 2010. http://dx.doi.org/10.1111/j.13652427.2009.02179.x.
OLIVEIRA, V. A. Diagnóstico dos usos da água na bacia do Ribeirão Ponte de Pedra (Mato Grosso) e seus efeitos sobre a qualidade da água. 2016. 63 f. Dissertação (Mestrado em Recursos Hídricos) - Universidade Federal do Mato Grosso, Cuiabá, 2016.

PETRUCIO, M. M.; BARBOSA, F. A. R.; THOMAZ, S. M. Bacteria and phytoplankton productions rates in eight river stretches of the middle Rio Doce hydrographic basin (Southeast Brazil). Brazilian Archives of Biology and Technology, v. 48, n. 3, p. 487-496, 2005. http://dx.doi.org/10.1590/S1516-89132005000300019.

POFF, N. L.; ALLAN, J. D.; BAIN, M. B.; KARR, J. R.; PRESTEGAARD, K. L.; RICHTER, B. D.; SPARKS, R. E.; STROMBERG, J. C. The natural flow regime: a paradigm for river conservation and restoration. Bioscience, v. 47, n. 11, p. 769-784, 1997. http://dx.doi.org/10.2307/1313099.

SANTOS, N. C. L.; GARCÍA-BERTHOU, E.; DIAS, J. D.; LOPES, T. M.; AFFONSO, I. P.; SEVERI, W.; GOMES, L. C.; AGOSTINHO, A. A. Cumulative ecological effects of a Neotropical reservoir cascade across mulitple assemblages. Hydrobiologia, v. 819, n. 1, p. 77-91, 2018. http://dx.doi.org/10.1007/s10750-018-3630-z.

SANTOS, N. C. L.; SANTANA, H. S.; DIAS, R. M.; BORGES, H. L. F.; MELO, V. F.; SEVERI, W.; GOMES, L. C.; AGOSTINHO, A. A. Distribution of benthic macroinvertebrates in a tropical reservoir cascade. Hydrobiologia, v. 765, n. 1, p. 265-275, 2016. http://dx.doi.org/10.1007/s10750-015-2419-6.

SOUZA, C. A.; SOUSA, J. B.; SILVA ANDRADE, L. N. P. Bacia Hidrográfica do Rio Jauru, Mato Grosso: dinâmica espacial e impactos associados. São Carlos: RiMa, 2012.

ZEILHOFER, P.; CALHEIROS, D. F.; OLIVEIRA, M. D.; CARVALHO DORES, E. F. G.; LIMA, G. A. R.; FANTINCRUZ, I. Pantanal floodplain and its contributing Cerrado upland rivers: implications for the interpretation of freshwater integrity. Wetlands Ecology and Management, v. 24, n. 6, p. 6, 2016. http:// dx.doi.org/10.1007/s11273-016-9497-8.

\section{Authors contributions}

Antônio Carlos Coelho da Silva: This article is based on research carried out as part of his MSc dissertation project on Water Resources. He was responsible for all data collection and analysis, part of the literature review and the initial write-up.

Ibraim Fantin-Cruz: Advised Author 1 about statistical analysis and ecohydrological approaches

Zoraidy Marques de Lima: Author 1's dissertation supervisor, designed the methodology and approach used in the study

Daniela Maimoni de Figueiredo: Author 1's co-supervisor, advised Author 1 about the limnological approach, added to the literature review, and wrote this article based on his dissertation text. 